\title{
Correction: Loss of miR-24-3p promotes epithelial cell apoptosis and impairs the recovery from intestinal inflammation
}

Artin Soroosh, Kai Fang, Jill M. Hoffman, Ivy K. M. Law, Elizabeth Videlock, Zulfiqar A. Lokhandwala (DD, Jonathan J. Zhao, Sepehr Hamidi, David M. Padua, Mark R. Frey, Charalabos Pothoulakis and Carl R. Rankin (D)

(c) The Author(s) 2022

Cell Death and Disease (2022)13:135; https://doi.org/10.1038/s41419-022-04559-5

Correction to: Cell Death \& Disease https://doi.org/10.1038/s41419021-04463-4, published online 18 December 2021

The original version of this article unfortunately contained a mistake. In the original version of this article, some data in Fig. 6 were presented incorrectly. The online version of this figure has been updated with the correct data. All the results previously reported as statistically significant remain so. There is no associated change to the text of the article. The authors regret this error. 
A
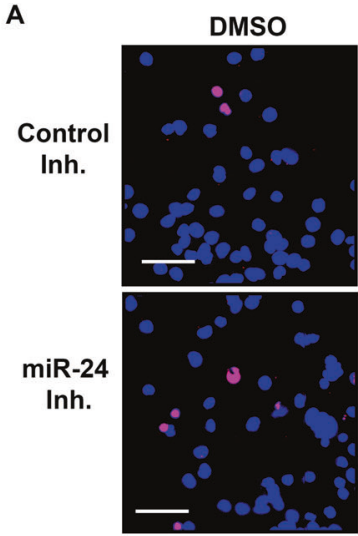

B

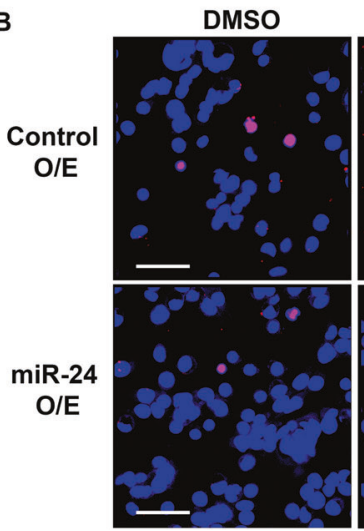

Staurosporine

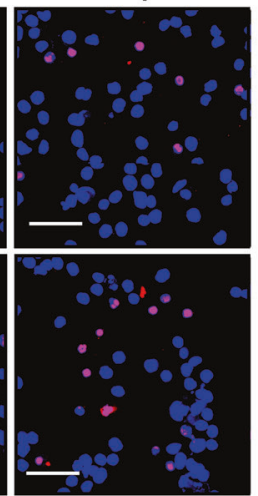

Staurosporine

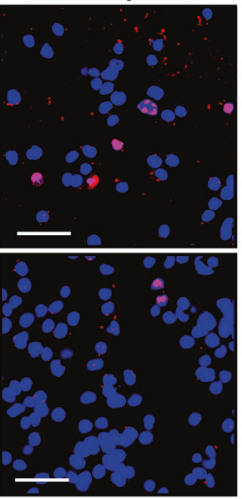

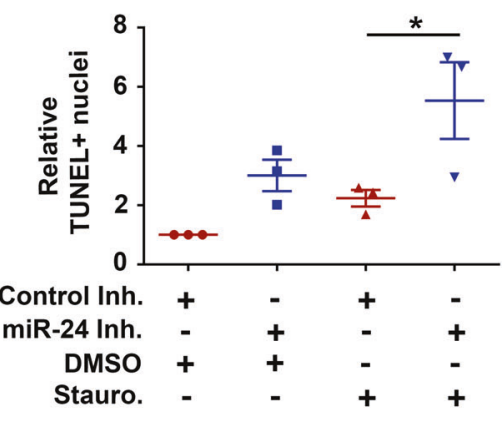

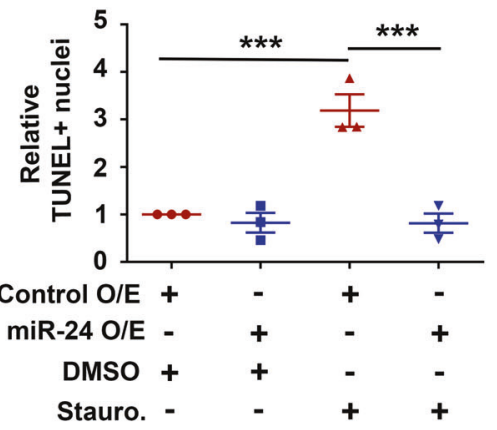

Fig. 6

Open Access This article is licensed under a Creative Commons Attribution 4.0 International License, which permits use, sharing, adaptation, distribution and reproduction in any medium or format, as long as you give appropriate credit to the original author(s) and the source, provide a link to the Creative Commons license, and indicate if changes were made. The images or other third party material in this article are included in the article's Creative Commons license, unless indicated otherwise in a credit line to the material. If material is not included in the article's Creative Commons license and your intended use is not permitted by statutory regulation or exceeds the permitted use, you will need to obtain permission directly from the copyright holder. To view a copy of this license, visit http://creativecommons. org/licenses/by/4.0/.

(c) The Author(s) 2022 